\title{
Youth Employment and Labor Market Vulnerability in Ghana: Aggregate Trends and Determinants
}

Adedeji Adeniran, Joseph Ishaku, and Adekunle Yusuf

\section{INTRODUCTION}

Because youth account for nearly a third, and an increasing percentage, of Africa's population, many scholarly and policy efforts aim to increase youth employment on the continent. Among recent such efforts, the African Union's ambitious Agenda 2063 development plan gives high priority to investing in youth as the driving force for achieving socioeconomic development in Africa (African Union Commission, 2015, p. 37). However, recent studies suggest that, unless proposed solutions are based on a thorough understanding of youth livelihood and employment realities, they are at risk of not achieving adequate impact and scale (Williams \& Pompa, 2017).

In order to contribute to this understanding, our study analyzed the circumstances of already employed youth in Ghana in order to assess their ability to enter and remain connected to the labor market across the dura-

\footnotetext{
A. Adeniran $(\bowtie) \bullet \mathrm{J}$. Ishaku $\bullet$ A. Yusuf

Centre for the Study of Economies of Africa (CSEA), Abuja, Nigeria e-mail: aadedeji@cseaafrica.org; jishaku@cseaafrica.org

(C) The Author(s) 2020

M. L. McLean (ed.), West African Youth Challenges and

Opportunity Pathways, Gender and Cultural Studies in Africa and the Diaspora, https://doi.org/10.1007/978-3-030-21092-2_9
} 
tion of active life. Based on the assumption that any larger effort to bring about full employment depends partly on the durability of new employment opportunities as well as access to them, our goal was to understand the extent and determinants of youth labor market vulnerability. The study illuminated key variables that shape labor market conditions faced by youth, as compared to middle-aged ( 25 to 54 years) and older adults ( 55 to 64 years), somehow employed in Ghana. We found that these variables, which include gender, level of education, and geographical area as well as sector of employment, signal the trajectory of Ghanaian youths' work lives and the likelihood that labor market vulnerability early on will cast a shadow on their late adulthood years.

Focusing on South Africa, Bhorat, Lilenstein, Oosthuizen, and Thornton (2016) identify conditions that render workers vulnerable in the labor market, including "working in the informal sector; earning low wages relative to the cost of living; not having a written contract; working in adverse conditions; not having access to benefits; and a lack of job security" (p. 2). Approaching the issue from another angle, the World Bank (2018) World Development Indicator data project defines vulnerable employment based on employment status of workers. Basically, the World Bank considered only contributing family workers and individuals working in self-employment jobs or on their own account as being engaged in vulnerable employment. This is because contributing and own-account workers experience the vulnerable conditions enumerated by Bhorat, Lilenstein, et al. (2016). For this study, except where otherwise stated, we define vulnerability in the labor market along the World Bank approach; however, we added domestic workers and apprentices to the vulnerable employment class, given the context of Ghana's labor market. Specifically, domestic employees and apprentices in Ghana share similar conditions as contributing family and own-account workers within the labor market (see Barret et al., 2015).

Empirical studies have documented that Ghana's youth, defined as individuals aged 15 to 24 years, faces higher barriers in gaining access to, and progressing in, Ghana's labor markets than any other segment of the population (Baffour-Awuah, 2013). Several factors play into the labor market vulnerability of the youth overall and Ghanaian youth in particular. As young people seek to enter formal labor markets for the first time, employers may be reluctant to hire them on permanent contracts or on a full-time basis, and entry wages are likely to be lower. This is often the case 
as young people lack the previous experience that signals their productivity potential to prospective employers. Hence, youths are faced with the trade-off between taking up vulnerable employment or remaining unemployed indefinitely.

Labor market vulnerability is particularly harmful to youth: it has lifelong effects on income-referred to in the literature as wage-scarringand on employment stability. Existing research shows that these effects can have the long-term impact of diminishing young people's confidence and resilience in dealing with labor market opportunities and setbacks over the course of their working lives (see Gregg \& Tominey, 2004; Mavromaras, Sloane, \& Wei, 2013; Nilsen \& Reiso, 2011).

This study aimed to identify the specific areas in which the circumstances of Ghanaian youth deviated from adults competing within the same labor market, that is, to understand the nuances of youth labor market vulnerability. As a first step toward gaining this understanding we juxtaposed data on the labor market conditions of youth with data on older cohorts-middle-aged ( 25 to 54 ) and older-aged (55 to 64 ). We then estimated the probability of labor market vulnerability for youth and older cohorts based on the significant variables of gender, sector of employment, and geographic location.

Our analysis revealed that youth have a higher likelihood of being vulnerable in the Ghanaian labor market relative to older cohorts, even after controlling for their individual characteristics. Nonetheless, we identified gender, location of residence, education, and sector of employment as significant for the likelihood of being in vulnerable employment for youth and other cohorts. For instance, not surprisingly, we found that Ghanaian women experience a higher degree of labor market vulnerability than Ghanaian men, across all age cohorts. It has been well-documented that women face comparatively more labor market barriers than men, for instance, with respect to owning productive resources and pursuing economic and entrepreneurial opportunities (World Bank, 2016).

In addition, while labor market vulnerability generally declines as individuals attain higher levels of education, educated Ghanaian youth remain more vulnerable relative to older cohorts. For instance, the results suggest that a youth with tertiary-level education credentials and a middle-aged adult with no formal education have a similar likelihood of ending up with vulnerable employment. Highly formalized sectors, such as finance, insurance, and real estate, have the least likelihood of vulnerability for youth. 
However, the entry barriers to these sectors is high, and the proportion of youth employed in them is low.

A cross-cutting finding in our analysis is the U-shape phenomenon of vulnerability in the Ghanaian labor market, whereby high vulnerability is recorded in the early years, falls in middle age, and rises again as workers approach retirement. Another important contribution of this study is in our empirical approach. We estimate separately the vulnerability likelihood for different age cohorts to document the experiences for each cohort and likewise compare conditions across cohorts.

The next section of this chapter reviews the empirical literature on labor market vulnerability. This is followed by a discussion of key trends in Ghana's labor market over a ten-year period (2008-2017). The fourth section presents the theoretical framing of vulnerability in the literature, as a lens and in responding to the understanding of vulnerability. The fifth section presents the detailed methodological approach adopted in the present study. Results and analyses are presented in the sixth section, and we conclude with a summary and some policy options in the final section.

\section{REVIEW OF EMPIRICAL LiTERATURE}

The issue of relative vulnerability, which is the comparison of conditions faced by different groups of workers competing in the same labor market, has drawn wide scholarly interest. ${ }^{1}$ Collectively, the research to date shows there is no singular experience of labor market vulnerability. Differential vulnerability in the labor market can be based on education, age, family responsibility, occupation, industry, welfare, and the absence or presence of labor market protections (Arnold \& Bongiovi, 2013; Bălan, 2014; Saunders, 2003). Additionally, the structure of a labor market has consequences for participants' risk of vulnerability. For instance, the high level of informality that characterizes the economies of many countries in the Global South is linked with a higher risk of vulnerability in the labor market (International Labour Organization [ILO], 2015; Shehu \& Nilsson, 2014).

In their analysis of the extent of informal employment among youths in 20 "developing" economies based on school-to-work transition surveys, Shehu and Nilsson (2014) found that for young people in these countries,

\footnotetext{
${ }^{1}$ See, for example, Bălan (2014).
} 
the informal employment was the "standard" sector of employment. This finding supports the conclusion that, in many cases, informal employment represents the only option available to young people. The study also found that past working experience played a crucial role in determining vulnerability over a lifetime of labor market participation. At entry level, a lack of past labor market experience increased youths' risk of ending up in informal employment, and this and other inequalities in early life were likely to follow youths throughout their work lives. Sparreboom and Staneva (2014) reached a similar conclusion regarding the high vulnerability of the youths in the labor market, based on a sample of 28 low- and middleincome countries.

Studies on what makes youths more vulnerable than other cohorts have also revealed a plethora of factors that are largely country-/region-specific. For example, Bhorat, Oosthuizen, Sharp, Lilenstein, and Yu (2016) modeled the determinant of vulnerability in labor markets in selected lowincome countries in Africa. They find that labor force participation rates are generally higher for men than for women and that young people aged between 15 and 24 years tend to have a substantially higher underemployment rate than all other age cohorts. Furthermore, the authors estimate an employment probability equation and earnings function to explore drivers of vulnerability within the labor market. The results revealed the most significant determinants of vulnerability in low-income countries in Africa to be age, gender, location, education, employment industry, and dependency.

Calvès and Schoumaker (2004) used retrospective data in Burkina Faso to investigate and compare the labor market outcomes of youths against the labor market outcomes of older cohorts documented during their youth. Their data allowed them to compare the labor market outcomes of three different age cohorts, drawing upon longitudinal data on the youth stage of each cohort. The authors observed that the youngest cohort found paid employment at an older age relative to the oldest cohort, especially among males. Similarly, the youngest cohorts were less likely to find their first paid employment in the formal sector relative to the oldest cohort, meaning that youths in the study were more likely to start work in the informal sector today than they were in the past.

In a study of Global South countries, Sparreboom and Staneva (2014) reported that vulnerability among youths decreased with higher levels of education. The study also concluded that the level of vulnerability was in direct proportion to the level of economic development. They estimated 
that vulnerability is highest for youth in low-income countries $(70 \%)$, relative to their counterparts from lower middle-income countries $(31 \%)$ and upper middle-income countries $(23 \%){ }^{2}$ This finding is plausibly related to the observed correlation between the size of a country's informal sector and its level of economic development.

With respect to Ghana, studies, including World Bank (2016), Porter, Blaufuss, and Acheampong (2007), Aryeetey and Baah-Boateng (2015), and Barret et al. (2015), have examined the circumstances of youths who are vulnerable within the labor market. A key conclusion from these studies is that youth labor challenges stem from the low quality of jobs, rather than unemployment. In the Ghanaian context, low-quality jobs are characterized by low pay and absence of job security, contract, or health benefits. However, how youths' conditions compare to older cohorts, and the socioeconomic factors driving their vulnerability, are questions that are not clearly understood.

The present study seeks to fill the gap in the literature in two significant respects. First, it investigates the key drivers of vulnerability among youths rather than youth employment outcomes or job status-a key departure from previous studies. Second, the study compares drivers of vulnerability among the youths to older cohorts in order to determine the extent to which the identified factors persist over time.

\section{Stylized Facts About the Ghanaian Labor Market}

This section discusses what are widely considered to be key trends within Ghana's labor market between 2008 and 2017. This period coincided with the global financial meltdown that affected productivity and labor market activities around the globe. The period was also marked by significant Ghanaian government policy interventions around youth issues, such as the introduction of the National Youth Policy of Ghana in 2010. We focus on labor market conditions (participation, unemployment rate, and vulnerability) and circumstances of youth relative to other labor market participants.

${ }^{2}$ This is based on the World Bank country classification by level of income per capita. Benin and Bangladesh are examples of low-income countries, while Zambia and Ukraine are lower middle-income countries, and Tunisia and Brazil are upper middle-income countries. 


\section{Demographic Profile of the Youth in Ghana}

Table 9.1 describes the key demographic profile of youth in Ghana, as drawn from Youth Policy Factsheets (2014). Specifically, youth constitutes about $18.63 \%$ of the population, and $50.3 \%$ of the youth population are female. Youth literacy in Ghana is among the highest in Africa at $91.32 \%$ for males and $89.86 \%$ for females. In comparison, youth literacy for subSaharan African countries is about $77 \%$. The demographic analysis shows that Ghana has yet to experience a youth bulge, as the majority of the population is not within the youth age bracket. However, with $38 \%$ of the population less than 14 years old and an annual population growth rate of about $2.17 \%$, Ghana is on course to reach the stage for a youth bulge within the next 30 years. The implication of this population dynamic is that new entrants into the labor market will arrive at an increasing rate over the next 30 years. Therefore, to meet the lofty objective of Agenda 2063 in terms of providing decent jobs for all, the rate of job creation must exceed the arrival rate in the labor market.

\section{Labor Force Participation}

Labor force participation refers to the proportion of the working age population that is active within the labor market, through either being presently engaged or actively looking for work. In Ghana, labor force participation is high: according to World Bank (2018) close to $77 \%$ of the working population were recorded to be active in the labor market in

Table 9.1 A snapshot of youth demographic profile

\footnotetext{
Age distribution

$0-14$ years: $38.01 \%$

15-24 years: $18.63 \%$

25-55 years: $34.14 \%$

56-64 years: $4.97 \%$

65 years and over: $4.25 \%$

Gender distribution

Male: $49.7 \%$

Female: $50.3 \%$

Youth literacy rate

Male: $91.32 \%$

Female: $89.86 \%$
}

Source: Compiled from World Bank (2018) and Ghana Statistical Service Database (2019) 


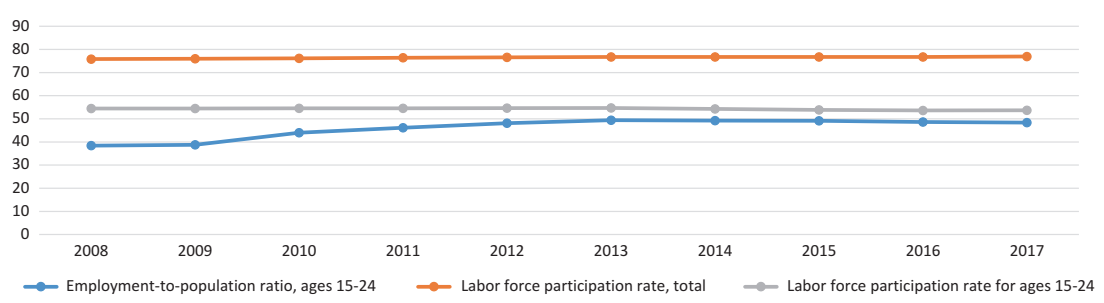

Fig. 9.1 Labor participation and employment-population in Ghana, 2008-2017 (Source: World Bank, 2018)

2017 (see Fig. 9.1). The participation rate is also stable over time, hovering around $74-77 \%$. As expected, the labor participation rate by the youth is much lower than for the entire population, estimated at $53.7 \%$ in 2017. The main reason for the low labor participation is the large number of youths in education and training-estimated at around $49.8 \%$ according to Ghana Living Standards Survey Round Six (GLSS 6) (Ghana Statistical Service, 2014).

Another important trend within the labor market, as shown in Fig. 9.1, is the employment-to-population ratio among the youth. The employmentto-population ratio measures the proportion of the working age population in a country that are employed. Although similar to the employment rate, it provides a much more relevant indicator of the potential of the economy to create jobs. Within the Ghanaian economy, the employmentto-population ratio for the youth stood at $51.1 \%$ in 2017 , an increase of 10 percentage points since 2008 (World Bank, 2018). Comparatively, the employment-to-population ratio for the entire population stood at $75 \%$ in 2017 and has remained fairly stable over time (World Bank, 2018).

However, the level of youth employment in Ghana masks a major issue around underemployment faced by youth within the labor market. According to GLSS 6 data, over 50\% of the young workers in Ghana are underemployed, compared to $35 \%$ for the entire labor force (Ghana Statistical Service, 2014).

\section{routh Unemployment}

Figure 9.2 shows the trend in unemployment rates between the youth and the total labor force in Ghana. The aggregate unemployment rate reached its peak in 2009 at $8.3 \%$, which reflects the negative effect of the global 


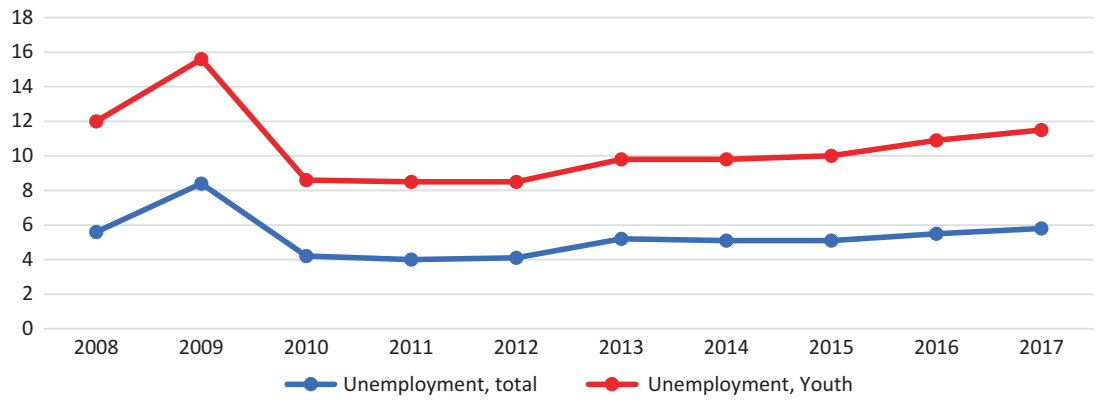

Fig. 9.2 Unemployment rate in Ghana, 2008-2017 (Source: World Bank, 2018)

financial meltdown (World Bank, 2018). Afterward, the unemployment rate stabilized at around $4-5 \%$, but there appears to be an uptick in recent years (World Bank, 2018). The youth unemployment rate, also shown in Fig. 9.2, is a mirror image of the rate for the aggregate population over the period. However, youth unemployment is consistently higher than the total unemployment over the period. This reflects the labor market condition for youths, in which they face less absorption and more stringent conditions for employment.

Ghana's youth unemployment is also exacerbated by the low level of formal education among young people. ${ }^{3}$ Only $7 \%$ of youth workers have attended university, vocational training, or other forms of postsecondary education. The lack of formal qualifications and skills makes it unlikely for youths to get employment in the formal sector (with high pay and more job security). The absence of formal education and the inability of the formal sector to adequately absorb the large population of job seekers have led to the informal sector becoming the only viable channel of employment for youth (Ismail, 2016).

Furthermore, the relatively high youth unemployment rate is fueled by socioeconomic circumstances such as rural-urban migration. For example, the Ashanti and Brong-Ahafo regions, the country's most urbanized areas, are home to a large portion of youths ${ }^{4}$ that are in search of opportunities

${ }^{3}$ The point here is that lack of formal education by a majority of the youth means they have a chance in only the informal sector, whereas the older cohorts have the opportunity to draw on both formal and informal sectors.

${ }^{4}$ This is a global phenomenon which Ghana is not immune from. In every country of the world, urban unemployment is always higher than rural unemployment. The Haris-Todaro model captures this idea vividly. 
in the formal sector. Generally, the average unemployment rate in urban areas exceeded those in rural areas by about 50 percentage points between 2000 and 2013 (Aryeetey \& Baah-Boateng, 2015). In essence, the young population is inadequately absorbed into employment compared with the older adult cohort.

On the surface, Ghana's high youth unemployment is in stark contrast to the sustained economic growth recorded in the past three decades. However, data measuring sectoral performance reveals that the growth is concentrated in non-employment-generating sectors (such as the oil sector), while there is a decline in growth of employment-generating sectors (such as agriculture and industry).

\section{Vulnerability in the Labor Force Market}

The dearth of opportunities in Ghana's formal sector pushes significant numbers of people toward vulnerable employment. Using World Bank data, Fig. 9.3 illustrates the proportion of workers in Ghana that can be classified as vulnerable. Vulnerability is measured as the sum total of the labor force population classified as own-account or self-employed and contributing family workers (those working for members within their household).

The proportion of vulnerable employment for the entire population fell from 76\% in 2008 to 68\% in 2017 (World Bank, 2018). However, women are still mostly engaged in vulnerable employment, $78 \%$ in 2017 , compared to $58 \%$ for men (World Bank, 2018). There are two perspectives to the high level of vulnerability faced by women in the labor force. On one side

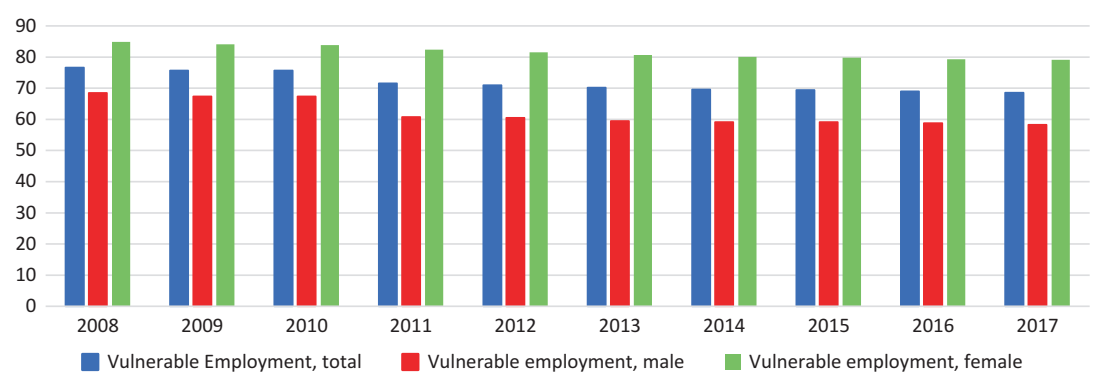

Fig. 9.3 Vulnerable employment in Ghana, 2008-2017 (Source: World Bank, 2018) 
are the structural factors such as cultural practices and taboos that affect mostly women. On the other hand, the increase in labor participation of women could also play a role. As Aryeetey and Baah-Boateng (2015) observed, high labor participation of women against the backdrop of fewer employment opportunities makes them more vulnerable. The condition for young women is even more severe, as they combine job searching with motherhood.

While this result represents the entire labor force, it is possible to draw an inference regarding the circumstances of the youth. The fact that youths are dominant in the informal sector clearly suggests they will be more vulnerable (see Aryeetey \& Baah-Boateng, 2015). Also, based on earnings data reported in Baah-Boateng, Ansu, and Amoak-Tuffour (2013), the least paid workers in Ghana are the contributing family and own-account workers, earning the equivalent of about $\$ 2.25$ and $\$ 4.95$ per day, respectively. In comparison, workers in wage employment earn \$10 per day, while employers earn \$20 per day. Similarly, formal sector workers (private and public) earn at least $\$ 15.35$ daily, while informal sector workers earn $\$ 5.75$ daily (Baah-Boateng et al., 2013). Essentially, since the majority of the youth workers are within the informal sector, where they are engaged mostly as contributing family or own-account workers, they are more likely to be poorly remunerated and therefore likely end up in vulnerable employment.

\section{Conceptual Framework}

Following the observation that youths are more exposed to vulnerability in the labor market relative to other age groups, we discuss some notable labor market theories that explain this observed pattern. Specifically, we discuss the labor market features that make youths more susceptible, over and beyond some of their individual characteristics that may contribute to their risk of vulnerability. This will help to situate the analysis of vulnerability within the context of labor market features that are amenable to policy fine-tuning.

The greater exposure of youths to labor market vulnerability is often explained using neoclassical economic theories, particularly the job search, school-to-work transition, and human capital theories (Doeringer \& Piore, 1975). For instance, these theories postulate that youth unemployment is a form of frictional unemployment arising due to skill 
mismatch between work demand and educational setting. This observation suggests a minimal role for policy intervention. Specifically, the theories rely on market mechanism to correct the mismatch. Also, this class of theories suggests the experience of vulnerability is a stage toward greater labor market integration in adult years and therefore policies should be directed toward supply-side interventions, so far as other dimensions of discrimination are not established among the youth population.

Another category of theories emphasizes the structural factors that make youths more vulnerable in the labor market. Some observable demographic and socioeconomic factors, among other structural drivers, disproportionately make youths more vulnerable (Barret et al., 2015; Dietritch, 2012; Sparreboom \& Staneva, 2014). Moreover, the effect of youth vulnerability in the labor market remains persistent for the most affected youths into adulthood (Mavromaras et al., 2013; Nilsen \& Reiso, 2011).

The internal and external labor market theory formulated by Doeringer and Piore (1970) is the theory most widely adhered to. The labor market is conceptualized as a segmented framework. Particularly, the internal labor market, characterized by high wages, good working conditions, and high job stability, is often shielded from direct competition with the external labor market, characterized by low wages, poor working conditions, and casual work, where most youths find themselves. The implication is therefore the concentration of youths in the external labor market.

We discuss these theories to analyze the Ghanaian labor market and explain recurrent unemployment spells-one of the drivers of labor market vulnerability among youths - as well as examine how these may affect labor market outcomes over time, as the statistics demonstrate. In the case of Ghana's labor market, structural theories tend to explain the pattern and level of vulnerability observed in the labor market. In particular, although youth are observed to be more vulnerable than older cohorts, all demographic groups are exposed to poor labor market outcomes, signaling structural problems within the labor market. The policy relevance of recognizing and understanding these segments within the labor market is the identification of two channels for intervention. The first channel is the possibility of introducing schemes that facilitate the mobility between the informal/external and formal/internal labor market. The second is the possibility of implementing schemes that improve the quality of jobs in the informal/external labor market. 


\section{Methodology}

This section details the empirical approach adopted in this study to measure vulnerability in the labor market. It also discusses the empirical strategy and dataset used in analyzing the conditions of the youth compared with older cohorts.

\section{Measuring Vulnerability from Employment Status}

According to the ILO (1993), workers can be classified under six employment status categories:

1. Wage and salaried workers: These are a class of employees who work in the formal sector, either private or public, and receive compensation in the forms of salary, wage, and commission. Workers in this setting are recognized as skilled components of the labor force and are often provided with formal contracts and better remuneration.

2. Employers: The ILO (1993) defines these workers as people working on their own account or with one or a few partners, and in this capacity, on a continuous basis (including the reference period) have engaged one or more persons to work for them in their business as employees.

3. Own-account workers: These are people that are self-employed and have not engaged any other employees to work for them. It is mostly borne out of failure to secure gainful employment within the formal sector.

4. Contributing family workers: According to the Organisation for Economic Co-Operation and Development (OECD) (2003), these are people who hold a self-employment job in a private establishment operated by a related person living in the same household, and who cannot be regarded as a partner because of the degree of his or her commitment to the operation of the establishment, in terms of the working time or standard labor contract.

5. Domestic employees: This broadly entails work performed in or for the household. This class of employee has no explicit or implicit contract.

6. Apprentice: This type of employment dominates the informal economy and mostly engages the youths. Specifically, it entails a 
young apprentice learning a particular skill through observation and imitation. They receive compensation only to meet their basic living costs.

For this study, vulnerable employment is defined as workers within the last four employment statuses: own-account workers, contributing family workers, domestic employees, and apprentices. This definition builds on and extends the World Bank definition of vulnerability, which only includes own-account and contributing family workers. We add domestic employees and apprentices given the context of the labor market in Ghana. Domestic employees and apprentices are subjected to no formal contract and receive little remuneration. In many instances, they are paid in kind through foods, clothing, and other basic needs in exchange for their services. Also, apprentices often transition to own-account workers after graduation, thereby remaining within the vulnerable employment segment.

\section{Determining Why rouths Ave More Vulnerable}

The theoretical and empirical evidence discussed above shows that youths are more vulnerable in the Ghanaian labor market. This raises an important question as to why and what factors predispose them to labor market vulnerability. It also raises the question of what implications current labor market vulnerability might have for future labor market participation of youth as they transition into the middle and older cohorts.

To answer these questions, we divide participants in the labor market into three groups: (1) youths aged 15 to 24 years (those just entering the labor market), (2) middle-aged adults aged 25 to 54 years (those in their prime working lives), (3) older adults aged 55 to 65 years (those passing the peak of their career and approaching retirement). We then estimate the probability of being vulnerable under different socioeconomic profiles. For instance, to what extent does being female make youth vulnerable compared to male youths and females in the older cohorts, and how does this evolve over time? Exploring the dynamics of labor market vulnerability will indicate the future possibilities for youths as they transition to adulthood. This illustrates the business-as-usual scenario in which, if there is no concerted effort from government, the vulnerability persists into adulthood and is even passed on to subsequent generations. 
The probability of being vulnerable is estimated based on a multiple logistic model in which our measure of vulnerability is regressed against some selected independent variables that have been observed in the literature to be likely drivers of vulnerability. For the statistical analysis, vulnerability is measured as a binary variable, which takes the value of "l" if a worker belongs to any of the four vulnerable classes of employment (own-account workers, contributing family workers, domestic employees, and apprentices), Otherwise, it takes the value of " 0 " if the worker is in wage and salary employment or is an employer. We then control for the following independent variables ${ }^{5}$ : gender, education level, industry of employment, location, and region. Any variable not significant at $10 \%$ level of significance is not reported.

\section{Data}

This study used data from the GLSS 6 by the Ghana Statistical Service (2014). Of the nationally representative sample of 18,000 households in 1200 enumeration areas, 16,772 were successfully enumerated leading to a response rate of 93.2\%. The GLSS 6 had a Labor Force Module that was used to collect data on labor indicators of 71,523 individual household members.

The GLSS 6 labor module sample contains observations for all individuals, irrespective of their ages and labor market participation status. However, seeing that this study focuses on examining labor market vulnerability constraints (i.e., conditions of potential and actual labor market participants), we streamlined the sample to include only individuals aged between 15 and 65 years (which is the official labor market participation age in Ghana), and we also dropped all people in the sample who are enrolled in educational institutions. There is considerable evidence in the literature to show that the proportion of younger people participating in the labor force is generally less than that for older age groups due to schooling. Hence, removing all individuals enrolled in educational programs or schools means that the analysis can be narrowed essentially to account for the conditions of young people who are participants in the Ghanaian labor market. Given that our sample targets individuals actively engaged in the labor market, we also exclude discouraged workers, retir-

${ }^{5}$ All the independent variables are measured as a categorical variable. 
ees, dependents, housewives, the disabled or sick, and redundant workers. Hence, the sample size is reduced to 33,687 individuals.

\section{EMPIRICAL RESULTS}

This section presents the result of the multiple logistic regression. The full result is presented in Table 9.6 in the Appendix. However, for ease of exposition, we extract from the full result estimated vulnerability probability by gender (Table 9.2), location (Table 9.3), education (Table 9.4), and industry of employment (Table 9.5).

\section{An Assessment of the Vulnerability of Youths Vis-à-Vis Other Cohorts}

\section{Gender}

Table 9.2 reports the vulnerability likelihood across gender. The rows show the estimated probability across age cohorts, while the columns compare vulnerability between males and females. There is about a $90 \%$ chance of being vulnerable for female youths in the labor market compared to about $85 \%$ for males. However, some interesting dynamics emerge when comparison is made across age cohorts. Vulnerability probability declines to about $79 \%$ for females in the middle age group but is elevated again to $85 \%$ for older adults. A similar pattern is observed for males and by extension across other socioeconomic profiles analyzed below. This suggests a U-shape relationship between age level and vulnerability. It also confirms the general hypothesis of this study that youths are more vulnerable and that this is due to underlying structural issues.

The observed higher vulnerability probability for women in the labor market can be explained in terms of structural factors that are not favorable to women and, therefore, hamper their effective participation in decent wage employment. For example, according to GLSS 6, Ghanaian

Table 9.2 Vulnerability probability by gender

\begin{tabular}{lccc}
\hline Gender & $15-24$ years & 25-54 years & 55-65 years \\
\hline Female & 0.9009 & 0.7898 & 0.8452828 \\
Male & 0.8496 & 0.6543 & 0.772681 \\
\hline
\end{tabular}

Source: Extracted from the multiple logistic regression in Table 9.6 in the Appendix 
women are less likely to attend schools, relative to their male counterparts (Ghana Statistical Service, 2014). From the survey data, about 36\% of females that are actively engaged in the labor force never attended school, compared to $22 \%$ of males. Another reason for the high vulnerability of females in the labor market in Ghana is the fact that women tend to face greater constraints in owning productive resources or accessing capital to expand their businesses and are therefore limited in economic and entrepreneurial opportunities (World Bank, 2016).

\section{Location}

Location has a significant influence on the probability of being in vulnerable employment in Ghana. The result in Table 9.3 indicates that vulnerability likelihood is higher for youths in rural areas compared to those in urban areas, although the difference is marginal. Focusing on regional variation in vulnerability, we found that youths in Greater Accra have the least probability of being engaged in vulnerable employment (with about $77 \%$ probability) while those in the Northern and Upper East region are the most vulnerable (with probability of about $91 \%$ and $92 \%$, respectively).

Greater Accra is the administrative seat of Ghana and the most urbanized region in the country, with about $87.4 \%$ of its inhabitants living in urban centers (Songsore, 2009). The region has a high level of commercial and governmental activities as well as some reasonable degree of industrial ventures. Therefore, workers in Greater Accra are more likely to

Table 9.3 Vulnerability probability by location

\begin{tabular}{lccc}
\hline Residence & 15-24 years & 25-54 years & 55-65 years \\
\hline Rural residence & 0.8842 & 0.7553 & 0.8296 \\
Urban residence & 0.8718 & 0.7050 & 0.7864 \\
Region & & & \\
Western & 0.863 & 0.6755 & 0.7933 \\
Central & 0.8357 & 0.7418 & 0.8285 \\
Greater Accra & 0.777 & 0.652 & 0.7558 \\
Volta & 0.900 & 0.769 & 0.8538 \\
Eastern & 0.870 & 0.7420 & 0.8099 \\
Ashanti & 0.869 & 0.7304 & 0.808 \\
Brong-Ahafo & 0.898 & 0.751 & 0.823 \\
Northern & 0.917 & 0.794 & 0.862 \\
Upper East & 0.923 & 0.752 & 0.822 \\
\hline
\end{tabular}

Source: Extracted from the multiple logistic regression in Table 9.6 
engage in wage employment than other regions in Ghana-an explanation for the relatively low probability of employment vulnerability in the region.

On the other hand, the Northern region, although the largest in terms of landmass, has a drier climate with $73 \%$ of its economically active population involved in agriculture (Ghana Statistical Service, 2013). Also, the Upper East region is the least urbanized part of Ghana. The region's economy is based on agriculture-primarily cattle rearing and planting of cereals such as rice, millet, and sorghum (Government of Ghana, Department of Children and United Nations International Children's Emergency Fund [UNICEF], n.d.). Generally, workers in the region are mostly peasant farmers and are vulnerable to adverse weather and other climateinduced shocks. This may explain the higher probability of employment vulnerability in the region.

Furthermore, youths are the most vulnerable group across regions in Ghana, and this is true for both industrial and agrarian regions. Again, we found a U-shape relation between vulnerability and age cohort, such that vulnerability reduces after transition from youth to middle age but increases thereafter. Again, this illustrates that in a business-as-usual scenario, vulnerable youths in Ghanaian society will simply transition to vulnerable adults. Therefore, there is likely to be low intergeneration mobility in economic opportunities and performance, thereby creating a vicious cycle perpetuating vulnerability from parents to their offspring. In essence, there is an urgent need to address the development challenges facing the rural and agrarian areas in Ghana.

\section{Education}

The analysis of vulnerability across levels of education attainment shows that Ghanaian workers with primary education have the most vulnerable employment, while those with university education record the least vulnerability (see Table 9.4). For the entire labor market, workers with university education are also the least likely to be in vulnerable employment $-75 \%$ for youths, $58 \%$ for middle age, and $63 \%$ for the older cohort.

Another noteworthy finding is the lower vulnerability probability recorded by youths with no education compared to those with primary and adult education. This could be explained by a lack of integration between lower-level education and the labor market in Ghana. For example, Ghana's Ministry of Employment and Labor Relations noted that the 
Table 9.4 Vulnerability probability by education

\begin{tabular}{lccc}
\hline Educational attainment & 15-24 years & 25-54 years & 55-65 years \\
\hline No formal education & 0.8730 & 0.7618 & 0.8425 \\
Primary education & 0.9012 & 0.7377 & 0.8154 \\
Secondary education & 0.8386 & 0.6993 & 0.7336 \\
Technical education & 0.7667 & 0.6476 & 0.7293 \\
Tertiary education & 0.7510 & 0.5865 & 0.6328 \\
Formal adult education & 0.9076 & 0.7546 & 0.8541 \\
\hline
\end{tabular}

Source: Extracted from the multiple logistic regression in Table 9.6

high level of youth unemployment in the country is partly due to the introduction of the Junior and Senior High School (JHS and SHS) systems without adequate planning for integrating them into trade/vocation and job placement (Baffour-Awuah, 2013). Specialized technical and vocational training for young people in Ghana, therefore, represent a viable option to reduce vulnerability and further systematically integrate the skillset acquired from schooling and labor market skill requirements.

\section{Industry of Employment}

In terms of the industry of employment, youths engaged in the agricultural $(98 \%)$ and manufacturing sector $(81 \%)$ are the most vulnerable (see Table 9.5). A similar pattern holds for middle-aged and older adults.

Table 9.5 Vulnerability probability by industry of employment

\begin{tabular}{llcl}
\hline Industry & 15-24 years & 25-54 years & 55-65 years \\
\hline Agriculture and fishing & 0.9782 & 0.9143 & 0.915 \\
Mining & 0.2269 & 0.2102 & - \\
Manufacturing & 0.8102 & 0.6622 & 0.736 \\
Electricity and utilities & 0.2704 & 0.2325 & - \\
Construction & 0.5672 & 0.5103 & 0.317 \\
Commerce & 0.787 & 0.7316 & 0.827 \\
Transportation \& communication & 0.479 & 0.3659 & 0.3089 \\
Financial, insurance, \& real estate & 0.129 & 0.2071 & 0.138 \\
Public administration & - & 0.0259 & 0.0899 \\
Education, health \& social work & 0.1232 & 0.0910 & 0.2108 \\
\hline
\end{tabular}

Note that "-" means the vulnerability probability is not reported because the coefficient is not statistically significant

Source: Extracted from the multiple logistic regression in Table 9.6 
Interestingly, youths in the financial sector are the least vulnerable, even better off than the other cohorts. This may be due to the stringent entry requirements into the sector relative to other economic sectors and the preference of formal financial firms for young graduates in Ghana for entry-level positions. Similarly, those in the mining, education and health services, and electricity sectors fare well in the labor market. However, the proportion of youth in these sectors is low. The overall analysis indicates that youths are in fact better off in more formal sectors. This, therefore, suggests that a crucial pathway to reduce youth vulnerability will be through the expansion of formal sector employment and equipping youths with school-to-work transition skills to secure formal jobs.

\section{CONCLUSION}

This study has examined the extent and determinants of vulnerability among youths in the Ghanaian labor market. The results of the study largely support the extant literature that youths aged 15 to 24 years are more vulnerable than older cohorts, both in accessing the formal sector and in transitioning from formal to informal employment. The fact of Ghanaian youths' lack of access to standard work offered within formal employment has far-reaching and lifelong wage and income scarring effects. The study revealed that one aspect of the scarring effect is a dynamic in which for any given socioeconomic profile, vulnerability is high for workers that are young, falls for those in the middle age, and rises again as workers approach retirement. This trend reveals the likely trajectory of youths' work lives as they transition to adulthood and the persistence of vulnerability. Hence, in order to mitigate labor market vulnerability in Ghana, youths and older adults should figure high among priorities for policy intervention.

We also conclude that policies and actions aimed at enhancing the overall social mobility of young people in Ghana will be more effective if planned to fit specific contexts. For instance, establishing mechanisms to ensure mobility from work back to school could be instrumental in enabling youths to move from informal to formal sector employment. Interventions such as this combined with ongoing efforts aimed at revamping vocational education and integrating it with the school curriculum will be an important public policy. 


\section{APPENDix}

Table 9.6 Multiple logistic regression of labor market vulnerability equation for various age cohorts in Ghana (dependent variable: vulnerability)

\begin{tabular}{|c|c|c|c|}
\hline Independent variable & $15-24$ years & 25-54 years & $55-65$ years \\
\hline \multicolumn{4}{|l|}{ Gender } \\
\hline Female & $\begin{array}{l}0.9009033 * * * \\
(0.0035166)\end{array}$ & $\begin{array}{l}0.7898811 * * * \\
(0.0031177)\end{array}$ & $\begin{array}{l}0.8452828 * * * \\
(0.0067626)\end{array}$ \\
\hline Male & $\begin{array}{l}0.8496206 * * * \\
(0.0047919)\end{array}$ & $\begin{array}{l}0.6543065 * * * \\
(0.0042217)\end{array}$ & $\begin{array}{l}0.772681 * * * \\
(0.0089811)\end{array}$ \\
\hline \multicolumn{4}{|l|}{ Location of residence } \\
\hline Rural residence & $\begin{array}{l}0.8842404 * * * \\
(0.0040609)\end{array}$ & $\begin{array}{l}0.755368 * * * \\
(0.0035761)\end{array}$ & $\begin{array}{l}0.8296399 * * * \\
(0.0070999)\end{array}$ \\
\hline Urban residence & $\begin{array}{l}0.8718873 * * * \\
(0.0043638)\end{array}$ & $\begin{array}{l}0.7050978 * * * \\
(0.003794)\end{array}$ & $\begin{array}{l}0.7864635 * * * \\
(0.0098311)\end{array}$ \\
\hline \multicolumn{4}{|l|}{ Educational attainment } \\
\hline No formal education & $\begin{array}{l}0.8561391 * * * \\
(0.0107763)\end{array}$ & $\begin{array}{l}0.7461034 * * * \\
(0.0053209)\end{array}$ & $\begin{array}{l}0.8405594 * * * \\
(0.0093703)\end{array}$ \\
\hline Primary education & $\begin{array}{l}0.8973997 * * * \\
(0.0050702)\end{array}$ & $\begin{array}{l}0.7378416 * * * \\
(0.0064008)\end{array}$ & $\begin{array}{l}0.8124948 * * * \\
(0.0172303)\end{array}$ \\
\hline Secondary education & $\begin{array}{l}0.8450967 * * * \\
(0.0085607)\end{array}$ & $\begin{array}{l}0.7094158 * * * \\
(0.0079946)\end{array}$ & $\begin{array}{l}0.7421411 * * * \\
(0.0361786)\end{array}$ \\
\hline Technical education & $\begin{array}{l}0.7913415 * * * \\
(0.0300716)\end{array}$ & $\begin{array}{l}0.6683465 * * * \\
(0.013463)\end{array}$ & $\begin{array}{l}0.7353936 * * * \\
(0.0309056)\end{array}$ \\
\hline Tertiary education & $\begin{array}{l}0.7648842 * * * \\
(0.0472552)\end{array}$ & $\begin{array}{l}0.6152413 * * * \\
(0.0168964)\end{array}$ & $\begin{array}{l}0.6524647 * * * \\
(0.0480943)\end{array}$ \\
\hline Formal adult education & $\begin{array}{l}0.8771642 * * * \\
(0.0611978)\end{array}$ & $\begin{array}{l}0.7386784 * * * \\
(0.0165824)\end{array}$ & $\begin{array}{l}0.8589 * * * \\
(0.0261744)\end{array}$ \\
\hline \multicolumn{4}{|l|}{ Industry of employment } \\
\hline Agriculture and fishing & $\begin{array}{l}0.9756471 * * * \\
(0.00231)\end{array}$ & $\begin{array}{l}0.9098103 * * * \\
(0.0035101)\end{array}$ & $\begin{array}{l}0.9145664 * * * \\
(0.006775)\end{array}$ \\
\hline Mining & $\begin{array}{l}0.2526738 * * * \\
(0.0469135)\end{array}$ & $\begin{array}{l}0.2278755 * * * \\
(0.0275475)\end{array}$ & \\
\hline Manufacturing & $\begin{array}{l}0.8205489 * * * \\
(0.014968)\end{array}$ & $\begin{array}{l}0.6697519 * * * \\
(0.0107243)\end{array}$ & $\begin{array}{l}0.7514908 * * * \\
(0.0301686)\end{array}$ \\
\hline Electricity and utilities & $\begin{array}{l}0.2896095 * \\
(0.1567811)\end{array}$ & $\begin{array}{l}0.2411071 * * * \\
(0.0606977)\end{array}$ & \\
\hline Construction & $\begin{array}{l}0.5952893 * * * \\
(0.0401123)\end{array}$ & $\begin{array}{l}0.5241562 * * * \\
(0.0195731)\end{array}$ & $\begin{array}{l}0.3393696 * * * \\
(0.0781089)\end{array}$ \\
\hline Commerce & $\begin{array}{l}0.8053336 * * * \\
(0.0122775)\end{array}$ & $\begin{array}{l}0.742422 * * * \\
(0.0071915)\end{array}$ & $\begin{array}{l}0.8317581 * * * \\
(0.0180033)\end{array}$ \\
\hline Transportation \& communication & $\begin{array}{l}0.5224159 * * * \\
(0.0399782)\end{array}$ & $\begin{array}{l}0.3806821 * * * \\
(0.0187189)\end{array}$ & $\begin{array}{l}0.3108498 * * * \\
(0.0705853)\end{array}$ \\
\hline
\end{tabular}


Table 9.6 (continued)

\begin{tabular}{|c|c|c|c|}
\hline Independent variable & $15-24$ years & $25-54$ years & $55-65$ years \\
\hline Financial, insurance, \& real estate & $\begin{array}{l}0.139791 * \\
(0.0746769)\end{array}$ & $\begin{array}{l}0.2219283 * * * \\
(0.0469038)\end{array}$ & $\begin{array}{l}0.1507738 \\
(0.132958)\end{array}$ \\
\hline Public administration & & $\begin{array}{l}0.0256245 \\
(0.0196327)\end{array}$ & $\begin{array}{l}0.0901949 \\
(0.0704513)\end{array}$ \\
\hline Education, health \& social work & $\begin{array}{l}0.1396186 * * * \\
(0.0358978)\end{array}$ & $\begin{array}{l}0.0845015 * * * \\
(0.0112126)\end{array}$ & $\begin{array}{l}0.2013682 * * * \\
(0.042313)\end{array}$ \\
\hline \multicolumn{4}{|l|}{ Region } \\
\hline Western & $\begin{array}{l}0.8631071 * * * \\
(0.0090033)\end{array}$ & $\begin{array}{l}0.6755129 * * * \\
(0.0077349)\end{array}$ & $\begin{array}{l}0.7933918 * * * \\
(0.0174239)\end{array}$ \\
\hline Central & $\begin{array}{l}0.8357605 * * * \\
(0.01334)\end{array}$ & $\begin{array}{l}0.7418513 * * * \\
(0.0077793)\end{array}$ & $\begin{array}{l}0.8285589 \text { *** } \\
(0.0150804)\end{array}$ \\
\hline Greater Accra & $\begin{array}{l}0.7773982 * * * \\
(0.0149158)\end{array}$ & $\begin{array}{l}0.652552 * * * \\
(0.0077525)\end{array}$ & $\begin{array}{l}0.7558884 * * * \\
(0.0222083)\end{array}$ \\
\hline Volta & $\begin{array}{l}0.9000875 * * * \\
(0.0087484)\end{array}$ & $\begin{array}{l}0.7691318 * * * \\
(0.007092)\end{array}$ & $\begin{array}{l}0.8538841 \text { *** } \\
(0.0138621)\end{array}$ \\
\hline Eastern & $\begin{array}{l}0.8709197 * * * \\
(0.0085545)\end{array}$ & $\begin{array}{l}0.7420323 * * * \\
(0.0071657)\end{array}$ & $\begin{array}{l}0.8099771 \text { *** } \\
(0.013989)\end{array}$ \\
\hline Ashanti & $\begin{array}{l}0.8693569 * * * \\
(0.0086308)\end{array}$ & $\begin{array}{l}0.7304593 * * * \\
(0.0066556)\end{array}$ & $\begin{array}{l}0.8082494 * * * \\
(0.0150767)\end{array}$ \\
\hline Brong-Ahafo & $\begin{array}{l}0.8987747 * * * \\
(0.0082098)\end{array}$ & $\begin{array}{l}0.7516783 * * * \\
(0.0074132)\end{array}$ & $\begin{array}{l}0.823182 * * * \\
(0.0164098)\end{array}$ \\
\hline Northern & $\begin{array}{l}0.9179383 * * * \\
(0.0074342)\end{array}$ & $\begin{array}{l}0.7940117 * * * \\
(0.0068935)\end{array}$ & $\begin{array}{l}0.8620807 * * * \\
(0.0144685)\end{array}$ \\
\hline Upper East & $\begin{array}{l}0.9235513 * * * \\
(0.0054311)\end{array}$ & $\begin{array}{l}0.7522132 * * * \\
(0.01432)\end{array}$ & $\begin{array}{l}0.8229605 * * * \\
(0.02239)\end{array}$ \\
\hline
\end{tabular}

Source: Authors' computation

Notes: Standard errors are given below the coefficients. The asterisks indicate significance at the following levels: $* * * p<0.01, * * p<0.05, * p<0.1$

\section{REFERENCES}

African Union Commission. (2015). Agenda 2063. The Africa we want: A shared strategic framework for inclusive growth and sustainable development. First tenyear implementation plan: 2014-2023. Retrieved March 19, 2019, from http:/ www.un.org/en/africa/osaa/pdf/au/agenda2063-firstl0yearimplementation.pdf

Arnold, D., \& Bongiovi, J. R. (2013). Precarious, informalizing, and flexible work: Transforming concepts and understandings. American Behavioral Scientist, 57(3), 289-308. https://doi.org/10.1177/0002764212466239 
Aryeetey, E., \& Baah-Boateng, W. (2015). Understanding Ghana's growth success story and job creation challenges (No. 2015/140). Helsinki, Finland: The United Nations University World Institute for Development Economics Research (UNU-WIDER).

Baah-Boateng, W., Ansu, Y., \& Amoak-Tuffour, J. (2013). Mapping of country information on employment, unemployment and policy initiatives. Accra: African Center for Economic Transformation.

Baffour-Awuah, D. (2013). Effectiveness of Ghana's targeted actions to promote youth employment. Abidjan, Côte d'Ivoire: Association for the Development of Education in Africa. Retrieved January 22, 2017, from http://www.adeanet. org/min_conf_youth_skills_employment/sites/default/files/u24/Ghana\%20 Country\%20Report_0.pdf

Bălan, M. (2014). Youth labor market vulnerabilities: Characteristics, dimensions and costs. Procedia Economics and Finance, 8, 66-72.

Barret, Z., Berrios, A., He, Y., Larsen, S., Novoa, M., Twumasi-Ankrah, K., et al. (2015). Youth employment in Ghana: Conditions and determinants. College Station, TX: Texas A \& M University, Bush School of Government \& Public Service.

Bhorat, H., Lilenstein, K., Oosthuizen, M., \& Thornton, A. (2016). Vulnerability in the labor market: Jobs, livelihood strategies \& poverty in South Africa. Rondebosch: University of Cape Town, Development Policy Research Unit.

Bhorat, H., Oosthuizen, M., Sharp, M., Lilenstein, K., \& Yu, D. (2016). Modelling labor markets in low income countries with imperfect data. Retrieved January 22, 2017, from http://conference.iza.org/conference_files/ GLMLICNetwork_2016/sharp_m24274.pdf

Calvès, A.-E., \& Schoumaker, B. (2004). Deteriorating economic context and changing patterns of youth employment in urban Burkina Faso: 1980-2000. World Development, 32(8), 1341-1354.

Dietritch, H. (2012). Youth unemployment in Europe: Theoretical considerations and empirical findings. Bonn: Friedrich Ebert Stiftung.

Doeringer, P. B., \& Piore, M. J. (1970). Internal labor markets and manpower analysis. Washington, DC: Manpower Administration (DOL), Office of Manpower Research.

Doeringer, P. B., \& Piore, M. J. (1975). Unemployment and the "dual labor market". The Public Interest, 38, 67-79.

Ghana Statistical Service. (2013). The 2010 population and housing census: National analytical report. Accra: Author. 
Ghana Statistical Service. (2014). Ghana living standards survey round 6 (GLSS 6) labor force report. Accra: Author.

Ghana Statistical Service. (2019). Demographic database. Retrieved January 24, 2019, from http://www.statsghana.gov.gh/nationalaccount_macros. php?Stats=MTA1NTY1NjgxLjUwNg==/webstats/s679n2sn87

Government of Ghana, Department of Children, \& United Nations International Children's Emergency Fund (UNICEF). (n.d.). Child protection baseline research: Upper East regional profile. Retrieved January 24, 2019, from https:// www.unicef.org/ghana/P1417_unicef_ghana_UPPER_EAST_WEB.pdf

Gregg, P., \& Tominey, E. (2004). The wage scar from youth unemployment (CMPO Working Paper Series No. 04/097). Bristol, England: Centre for Market and Public Organisation. Retrieved March 12, 2018, from http://www.bristol.ac. uk/media-library/sites/cmpo/migrated/documents/wp97.pdf

International Labour Organization. (1993). Resolution concerning the International Classification of Status in Employment (ICSE), adopted by the Fifteenth International Conference of Labour Statisticians. Retrieved March 12 , 2018, from https://www.ilo.org/wcmsp5/groups/public/\%2D\%2Ddgreports $\% 2 \mathrm{D} \% 2 \mathrm{D}$-stat/documents/normativeinstrument/wcms_ 087562.pdf

International Labour Organization (ILO). (2015). Global employment trends for youth 2015: Scaling up investments in decent jobs for youth. Geneva: Author.

Ismail, O. (2016). What is in a job? The social context of youth employment issues in Africa. Journal of African Economies, 25(suppl_1), i37-i60.

Mavromaras, K., Sloane, P., \& Wei, Z. (2013). The scarring effects of unemployment, low pay and skills under-utilisation in Australia compared. Bonn: Institute for the Study of Labor.

Nilsen, Q., \& Reiso, K. H. (2011). Scarring effects of unemployment. Bonn: Institute for Study of Labor.

Organisation for Economic Co-operation and Development (OECD). (2003). Glossary of statistical terms. Retrieved December 23, 2018, from https://stats. oecd.org/glossary/detail.asp?ID=443

Porter, G., Blaufuss, K., \& Acheampong, F. O. (2007). Youth, mobility and rural livelihoods in sub-Saharan Africa: Perspectives from Ghana and Nigeria: Poverty, development and livelihoods. Africa Insight, 37(3), 420-431.

Saunders, R. (2003). Defining vulnerability in the labor market. Ottawa: Canadian Research Policy Networks. Retrieved September 23, 2018, from http://www. envision.ca/pdf/w2w/definingvulnerability.pdf

Shehu, E., \& Nilsson, B. (2014). Informal employment among youth: Evidence from 20 school-to-work transition surveys. Geneva: International Labor Organisation (ILO). Retrieved September 23, 2018, from http://www.ilo. org/wcmsp5/groups/public/\%2D\%2D-dgreports/\%2D\%2D-dcomm/documents/publication/wcms_234911.pdf 
Songsore, J. (2009). The urban transition in Ghana: Urbanization, national development and poverty reduction. London: International Institute for Environment and Development.

Sparreboom, T., \& Staneva, A. (2014). Is education the solution to decent work for youth in developing economies? Identifying qualifications mismatch from 28 school-to-work transition surveys. Geneva: International Labor Organisation. Retrieved September 23, 2018, from http://www.un.org/youthenvoy/wpcontent/uploads/2014/10/Work4Youth-Publication.pdf

Williams, T., \& Pompa, C. (2017). Invisible lives: Understanding youth livelihoods in Ghana and Uganda. Toronto: The Mastercard Foundation. Retrieved March 19, 2019, from https://mastercardfdn.org/wp-content/ uploads/2018/05/Report_YouthLivelihoods_Feb2017v2-Accessible-3-1accessible.pdf

World Bank. (2016). Harnessing youth potential in Ghana: A policy note. Retrieved January 24, 2019, from http://documents.worldbank.org/curated/ en/299731470375262940/Harnessing-youth-potential-in-Ghana-a-policy-note World Bank. (2018). World development indicators. Retrieved January 24, 2019, from http://datatopics.worldbank.org/world-development-indicators/

Youth Policy Factsheets. (2014, June 11). Factsheet: Ghana. Retrieved January 23, 2017, from http://www.youthpolicy.org/factsheets/country/ghana/

Open Access This chapter is licensed under the terms of the Creative Commons Attribution 4.0 International License (http://creativecommons.org/licenses/ by $/ 4.0 /$ ), which permits use, sharing, adaptation, distribution and reproduction in any medium or format, as long as you give appropriate credit to the original author(s) and the source, provide a link to the Creative Commons licence and indicate if changes were made.

The images or other third party material in this chapter are included in the chapter's Creative Commons licence, unless indicated otherwise in a credit line to the material. If material is not included in the chapter's Creative Commons licence and your intended use is not permitted by statutory regulation or exceeds the permitted use, you will need to obtain permission directly from the copyright holder.

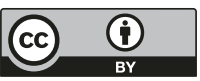

